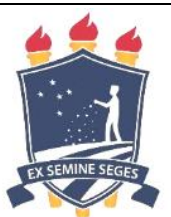

\title{
Evaluation of diets based on Brachiaria grass with different levels of byproducts from the biodiesel industry using in vitro gas production degradability
}

\author{
[Avaliação de dietas à base de capim Brachiaria com diferentes níveis de coprodutos da indústria \\ do biodiesel pela técnica de degradabilidade in vitro de produção de gás]
}

\section{"Scientific Article/Artigo Científico"}

\author{
Juliana Marques Freire ${ }^{1 *}$, Aderbal Marcos de Azevedo Silva ${ }^{2}$, Heloisa Carneiro $^{3 *}$, \\ José Morais Pereira Filho ${ }^{3}$, Daiane Caroline de Moura ${ }^{4}$, Jovanna Karine Pinheiro
}

\author{
${ }^{1}$ Departamento de Zootecnia, Universidade Federal de Mato Grosso, Cuiabá-MT, Brasil. \\ ${ }^{2}$ Departamento de Zootecnia, Universidade Federal de Campina Grande, Patos-PB, Brasil. \\ ${ }^{3}$ Empresa Brasileira de Pesquisa Agropecuária, Gado de Leite, Juiz de Fora-MG, Brasil. \\ ${ }^{4}$ Departamento de Zootecnia, Instituto Federal de Mato Grosso, Cidade-UF, Brasil. \\ ${ }^{5}$ Departamento de Medicina Veterinária, Universidade Federal de Campina Grande, Patos-PB, Brasil. \\ *Autor para correspondência/Corresponding author: E-mail: juliana.zoo@ hotmail.com; heloisa.carneiro@embrapa.br
}

\begin{abstract}
This study was performed to evaluate the production of gas and volatile fatty acids in diets containing byproducts from the national biodiesel industry (castor bean, canola, forage turnip, and black sunflower) in four levels $(0,30,50$ and $70 \%)$, through the use of a semi-automated in vitro technique. The inoculum for in vitro incubation was obtained from three fistulated Holstein cows. This was a 4 x 4 factorial completely randomized experimental design consisting of four levels of four byproducts. The byproduct of forage turnip was the ingredient of greatest potential for producing acetate, propionate, and butyrate. The increased production of carbon dioxide and methane in relation to the degraded dry matter was obtained using the byproduct of canola $(\mathrm{P}<0.05)$. The byproduct of castor bean resulted in the lowest potential for producing acetate, propionate, and butyrate; and among the evaluated byproducts it can be considered the one with the least impact to the environment without damage to ruminal fermentation.
\end{abstract}

Keywords: alternative food, digestibility, greenhouse effect, methanogenesis, environment.

\section{Resumo}

Este estudo foi realizado para avaliar a produção de gás e ácidos graxos voláteis em dietas contendo coprodutos da indústria nacional de biodiesel (mamona, canola, nabo forrageiro e girassol preto) em quatro níveis $(0,30$, 50 e 70\%), através do uso da técnica semiautomática in vitro. O inóculo para incubação in vitro foi obtido a partir de três vacas Holandesas fistuladas. O delineamento experimental foi de $4 \mathrm{x} 4$, com delineamento experimental inteiramente casualizado, constituído por quatro coprodutos e quatro níveis. O coproduto do nabo forrageiro foi o ingrediente de maior potencial de produção de acetato, propionato e butirato. $\mathrm{O}$ aumento da produção de dióxido de carbono e metano em relação à matéria seca degradada foi obtido utilizando-se o coproduto da canola $(\mathrm{P}<0,05)$. $\mathrm{O}$ coproduto da mamona resultou em menor potencial para a produção de acetato, propionato e butirato, podendo ser considerado entre os coprodutos avaliados o de menor impacto no meio ambiente sem prejuízo à fermentação ruminal.

Palavras-chave: alimentos alternativos; digestibilidade; efeito estufa; metanogênese; meio ambiente.

\section{Introduction}

The growing demand for food alternatives allows the use of byproducts, which enables the reduction of environmental impacts and production costs. Studies on the use of these ingredients allowed to know the nutritive value, after processing in the biodiesel industry, making them excellent food sources.

The biodiesel industry uses oilseeds for oil extraction (Abdalla et al., 2008), and due to this extensive production, there is a large amount of 
residues. The potential for suppling foods with high fiber content to ruminants allows a suitable destination for these residues and at the same time allows the replacement of commonly used forage in low cost food.

Byproducts arouse the interest as alternative sources for the mitigation of methane originating from the digestive process in ruminants. These foods have in their composition elements capable of acting on the rumen microbiota, either because of their high concentration of fatty acids, tannins, or non-structural carbohydrates.

Despite the potential for feeding ruminants, it is necessary to know, estimate and evaluate the effects of biodiesel byproducts on the performance and health of the animals (Azevedo et al., 2013). Due to these questions, techniques that simulate ruminal fermentation (in vitro gas production) and specific tests for supplied foods have been developed (Bueno et al., 2008).

The objective of this study was to evaluate the in vitro production of volatile fatty acids and methane from byproducts from the biodiesel industry (canola, forage turnip, black sunflower, and castor bean) after 48 hours of incubation in culture medium.

\section{Material and Methods}

The experiment was conducted at the Experimental Field of Coronel Pacheco, which is owned by Embrapa Dairy Cattle and located in the Zona da Mata of Minas Gerais - Minas Gerais State.

The substrates used for in vitro incubation were Marandu grass (Brachiaria brizantha Stapf cv. Marandu, 28 days cut) as control and byproducts from the biodiesel industry: castor bean (Ricinus communis L.), canola (Brassica napus L.), black sunflower (Helianthus annus L), and forage turnip (Raphanus sativus L.).

The substrates composed of byproducts and forage were oven-dried in forced ventilation at $55^{\circ} \mathrm{C}$ for 48 hours, then ground in a Wiley mill with $1.0 \mathrm{~mm}$ sieve to determine dry matter (DM) (Method 967.03 - Association of Official Analytical Chemists [AOAC], 1990). Ash (ASH), crude protein $(\mathrm{CP})$ and ether extract $(\mathrm{EE})$ were determined according to the procedures described in methods 942.05, 981.10 and 920.29 of AOAC (AOAC, 1990). To determine NDF and ADF, the methodology by Van Soest, Robertson, and Lewis (1991) was used, due to modifications proposed in the Ankon device manual (Ankon Technology Corporation Macedon, New York, USA).

For ruminal fluid collection, three Holstein cows averaging $600 \mathrm{~kg}$ and fistulated in the rumen were sampled; fluid was transferred to thermal bottles previously heated to $39^{\circ} \mathrm{C}$ and taken immediately to the laboratory. In the laboratory, the ruminal contents were homogenized and filtered through two layers of cotton cloth and kept in a water bath at $39^{\circ} \mathrm{C}$ under $\mathrm{CO}_{2}$ saturation until adding other solutions (buffer, macro- and microminerals, resazurin solution, and medium B) to the culture medium. The ruminal fluid and buffer solution were mixed at a proportion of 5:1 (Vitti et al., 1999).

The inoculum $(30 \mathrm{~mL})$ was then transferred to incubation flasks, sealed and placed on a rack orbital shaker set at 120 oscillations per minute in a $39^{\circ} \mathrm{C}$ incubator.

After the last measurement of gas at 48 hours post-incubation, the gas from each vial was collected and stored to determine the concentration of $\mathrm{CH}_{4}$ and $\mathrm{CO}_{2}$. The content of each vial was removed by means of $30 \mathrm{cc}$ plastic syringes and transferred immediately to $20 \mathrm{cc}$ amber flask in vacuum for sample storage. Afterwards, the fermentation flasks were opened and the $\mathrm{pH}$ of the culture medium was measured using a $\mathrm{pH}$ meter (Orion model 260A, Fisher Scientific, Toronto, ON, Canada).

The percentage of $\mathrm{CH}_{4}$ and $\mathrm{CO}_{2}$ was determined in the Laboratory of Chromatography of EMBRAPA - Dairy Cattle, located in the city of Juiz de Fora, State of Minas Gerais, using a gas chromatography apparatus (Fedorak and Hrudey, 1983). From the percentage of gas production, the volume corresponding to the accumulated gas production was calculated for 24 and 48 hours of the fermentation process, corrected for each gram of degraded dry matter. The results of methane and carbon dioxide were expressed in $\mathrm{mL} / \mathrm{DM}$ incubated.

To identify and quantify volatile fatty acids (VFAs), a liquid fraction of the culture medium (10 $\mathrm{mL}$ ) was collected after digestibility (48 hours) and $2 \mathrm{~mL}$ metaphosphoric acid (20\%) was added to the medium to preserve the sample, and then stored in a freezer until further analysis (Holtshausen et al., 2009).

For the identification and quantification of ammonia nitrogen $\left(\mathrm{NH}_{3}-\mathrm{N}\right)$, a liquid fraction of the culture medium $(10 \mathrm{~mL})$ was collected after 
digestibility (48 hours), then stored in a freezer until further analysis (Holtshausen et al., 2009).

The statistical design used to evaluate cumulative gas production and dry matter degradability was completely randomized in a $4 \mathrm{x}$ 4 factorial arrangement (4 byproducts and 4 substitution levels).

The production of $\mathrm{CH}_{4}, \mathrm{CO}_{2}$, VFAs, $\mathrm{pH}$, and $\mathrm{NH}_{3}$ were subjected to analysis of variance (Proc Anova $)$ in SAS where Tukey's test $(\mathrm{P}<0.05)$ was applied to the main factors of each substitution level. The results of the increasing levels were interpreted statistically through the regression models by PROC REG (SAS, 2003).

\section{Results and Discussion}

The evaluated byproducts showed high crude protein content (forage turnip and castor bean) and high content of ether extract (forage turnip) (Table 1).

Table 1. Chemical composition $(\mathrm{g} / \mathrm{kg})$ of Brachiaria grass and four substrates from the biodiesel industry, on a dry matter basis.

\begin{tabular}{lllllll}
\hline Ingredients & $\mathbf{D M}(\mathbf{g} / \mathbf{k g})$ & $\begin{array}{l}\mathbf{C P} \\
(\mathbf{g} / \mathbf{k g})\end{array}$ & $\begin{array}{l}\text { NDF } \\
(\mathbf{g} / \mathbf{k g})\end{array}$ & $\begin{array}{l}\text { ADF } \\
(\mathbf{g} / \mathbf{k g})\end{array}$ & $\begin{array}{l}\mathbf{E E} \\
(\mathbf{g} / \mathbf{k g})\end{array}$ & $\mathbf{D M D}(\mathbf{g} / \mathbf{k g})$ \\
\hline Brachiaria grass & 870.8 & 122.2 & 556.2 & 277.7 & 32.2 & 652 \\
\hline Forage turnip & 935.6 & 393.7 & 217.1 & 137.1 & 284.1 & 644.8 \\
Castor bean & 912.6 & 420.2 & 423.3 & 383.4 & 43.8 & 497.1 \\
Black sunflower & 901.1 & 342.6 & 390.1 & 243.6 & 32.1 & 582.3 \\
Canola & 922.1 & 375.1 & 410.3 & 378.3 & 24.3 & 689.1 \\
\hline
\end{tabular}

DM: dry matter; CP: crude protein; NDF: neutral detergent fiber; ADF: acid detergent fiber; EE: ether extract; DMD: dry matter digestibility.

The composition of the diet is very important when it is based on forage, as large proportions of structural carbohydrates produce large amounts of CH4 (Archimed et al., 2011)

The levels of interaction and substitution of byproducts to measure methane in vitro production were verified in the time interval of 48 hours (Table 2).

At the $30 \%$ level, there was a significant difference between the evaluated foods, with the highest methane production observed for canola. At levels of 50 and $70 \%$, canola and sunflower did not differ from each other, with these results superior when compared to forage turnip and castor bean.

Using the black sunflower byproduct, each percentage unit of replacement of Brachiaria grass with this byproduct, there was an increase of 0.50 $\mathrm{mL} / \mathrm{g}$ in methane production, while the byproducts of turnip and castor bean showed decreasing linear responses, with 0.13 and $0.37 \mathrm{~mL} / \mathrm{g} \quad \mathrm{CH}_{4}$, respectively. The decreasing response in methane production with the inclusion of forage turnip confirms the results reported by Abdalla et al. (2008), who detected significant differences for the inclusion of this byproduct, together with lupine cake.

With the use of byproducts, we expected a reduction in the levels of methane production, but when replacing Brachiaria grass with black sunflower and canola, we observed a high methane production, which is related to the content of fiber carbohydrates in these foods. Berchielli et al. (2006) stated that with the disappearance of the potentially digestible portion, there is a reduction in the digestion of a polymer. It becomes necessary a longer time of exposure to the microorganisms for digestion and production of VFA, as a consequence, production of methane gas.

When analyzing the replacement of Brachiaria grass with the castor bean byproducts, it was observed that their use resulted in the lowest levels of methane production and could be related to antinutritional compounds, such as ricin, which is harmful to ruminal microorganisms, and the high amount of polyunsaturated fatty acids present in its composition when compared to the others.

Analyzing the $\mathrm{CO}_{2}$ production, the interaction effect of byproducts and the substitution levels for the production of this gas was found with a time interval of 48 hours (Table 2).

Considering the production of $\mathrm{CO}_{2}$ in the replacement of 30 and $50 \%$ of byproducts, it was observed that canola presented a significant production differing from the others $(\mathrm{P}<0.05)$. At $70 \%$ substitution, byproducts of canola and black sunflower did not statistically differ from each other, maintaining their high $\mathrm{CO}_{2}$ production. 
Observing the substitution of Brachiaria grass, we observed a linear decreasing effect (P $<0.05$ ) when using forage turnip, for each $1 \%$ of the substitution level of this byproduct there was a decrease of $0.139 \mathrm{~mL} / \mathrm{g}$ in the production of enteric $\mathrm{CO}_{2}$, in turn, for the byproduct of castor oil, the reduction was $0.239 \mathrm{~mL} / \mathrm{g}$ in the production of enteric $\mathrm{CO}_{2}$.

Table 2. Production of $\mathrm{CH}_{4}, \mathrm{CO}_{2}, \mathrm{NH}_{3}-\mathrm{N}(\mathrm{mL} / \mathrm{g})$ and $\mathrm{pH}$, of biodiesel byproducts in different levels of substitution of Brachiaria grass.

\begin{tabular}{|c|c|c|c|c|c|c|c|}
\hline \multirow[t]{2}{*}{ Byproducts } & \multicolumn{4}{|c|}{ Replacement levels } & \multirow{2}{*}{ Regression equation } & \multirow{2}{*}{$\mathrm{R}^{2}$} & \multirow{2}{*}{$\mathrm{P}$} \\
\hline & $0 \%$ & $30 \%$ & $50 \%$ & $70 \%$ & & & \\
\hline \multicolumn{8}{|c|}{$\mathrm{CH}_{4}$} \\
\hline Forage turnip & $4.86^{\mathrm{A}}$ & $4.43^{\mathrm{C}}$ & $4.36^{\mathrm{B}}$ & $3.83^{\mathrm{B}}$ & $Y=4.887-0.013 x$ & 0.630 & 0.0021 \\
\hline Castor bean & $4.86^{\mathrm{A}}$ & $3.50^{\mathrm{D}}$ & $3.06^{\mathrm{B}}$ & $2.13^{\mathrm{C}}$ & $Y=4.808-0.037 x$ & 0.952 & $<0001$ \\
\hline Black sunflower & $4.86^{\mathrm{A}}$ & $6.50^{\mathrm{B}}$ & $8.63^{\mathrm{A}}$ & $7.93^{\mathrm{A}}$ & $\mathrm{Y}=5.097+0.050 \mathrm{x}$ & 0.778 & 0,0001 \\
\hline Canola & $4.86^{\mathrm{A}}$ & $9.33^{\mathrm{A}}$ & $10.40^{\mathrm{A}}$ & $8.66^{\mathrm{A}}$ & $Y=4.820+0.233 x-0.002 x^{2}$ & 0.921 & $<0001$ \\
\hline \multicolumn{8}{|c|}{$\mathrm{CO}_{2}$} \\
\hline Forage turnip & $25.20^{\mathrm{A}}$ & $21.00^{\mathrm{BC}}$ & $18.06^{\mathrm{C}}$ & $15.50^{\mathrm{B}}$ & $Y=25.169-0.139 x$ & 0.91 & $<0001$ \\
\hline Castor bean & $25.20^{\mathrm{A}}$ & $16.50^{\mathrm{C}}$ & $13.20^{\mathrm{C}}$ & $8.13^{\mathrm{C}}$ & $Y=24.826-0.239 x$ & 0.97 & $<0001$ \\
\hline Black sunflower & $25.20^{\mathrm{A}}$ & $24.40^{\mathrm{B}}$ & $28.83^{\mathrm{B}}$ & $24.96^{\mathrm{A}}$ & $\mathrm{Y}=25.235$ & - & NS \\
\hline Canola & $25.20^{\mathrm{A}}$ & $34.70^{\mathrm{A}}$ & $37.23^{\mathrm{A}}$ & $29.70^{\mathrm{A}}$ & $Y=24.942+0.578 \times 0.007 x^{2}$ & 0.79 & 0,0009 \\
\hline \multicolumn{8}{|c|}{$\mathrm{N}-\mathrm{NH}^{3}$} \\
\hline Forage turnip & $12.60^{\mathrm{A}}$ & $27.53^{\mathrm{C}}$ & $36.63^{C}$ & $43.63^{\mathrm{C}}$ & $Y=13.319+0.447 x$ & 0.972 & $<0001$ \\
\hline Castor bean & $12.60^{\mathrm{A}}$ & $14.23^{\mathrm{D}}$ & $21.00^{\mathrm{D}}$ & $27.53^{\mathrm{D}}$ & $Y=12.425-0.015 x+0.003 x^{2}$ & 0.982 & $<0001$ \\
\hline Black sunflower & $12.60^{\mathrm{A}}$ & $38.73^{\mathrm{B}}$ & $61.83^{\mathrm{A}}$ & $69.66^{\mathrm{B}}$ & $Y=11.874+1.118 x-0.003 x^{2}$ & 0.969 & $<0001$ \\
\hline Canola & $12.60^{\mathrm{A}}$ & $52.26^{\mathrm{A}}$ & $57.40^{\mathrm{A}}$ & $75.36^{\mathrm{A}}$ & $\mathrm{Y}=17.131+0860 \mathrm{x}$ & 0.941 & $<0001$ \\
\hline \multicolumn{8}{|c|}{$p H$} \\
\hline Forage turnip & $6.36^{\mathrm{A}}$ & $6.43^{\mathrm{B}}$ & $6.50^{\mathrm{B}}$ & $6.60^{\mathrm{B}}$ & $Y=6.352+0003 x$ & 0.837 & $<0001$ \\
\hline Castor bean & $6.36^{\mathrm{A}}$ & $6.60^{\mathrm{A}}$ & $6.70^{\mathrm{A}}$ & $6.80^{\mathrm{A}}$ & $Y=6.385+0.006 x$ & 0.964 & $<0001$ \\
\hline Black sunflower & $6.36^{\mathrm{A}}$ & $6.40^{\mathrm{BC}}$ & $6.40^{\mathrm{B}}$ & $6.50^{\mathrm{B}}$ & $\mathrm{Y}=6.353+0.001 \mathrm{x}$ & 0.619 & 00024 \\
\hline Canola & $6.36^{\mathrm{A}}$ & $6.30^{\mathrm{C}}$ & $6.33^{\mathrm{B}}$ & $6.40^{\mathrm{C}}$ & $Y=6.365-0.003 x+0.00006 x^{2}$ & 0.549 & 0.0276 \\
\hline
\end{tabular}

* Different letters in the same column indicate statistically different values by Tukey's test at $5 \%$ probability.

The byproduct of canola provided a quadratic effect considering the production of $\mathrm{CO}_{2}$ when replacing the Brachiaria grass, notably increasing its amounts. Being $60.5 \%$ the maximum point $(219.62 \mathrm{~mL} / \mathrm{g})$ of $\mathrm{CO}_{2}$ production of the canola byproduct.

Influence on $\mathrm{NH}_{3}-\mathrm{N}$ ratios in vitro in the 48hour time interval was verified using biodiesel byproducts in substitution of brachiaria grass.

The use of the canola byproduct resulted in an increasing production of $\mathrm{NH}_{3}-\mathrm{N}$ the evaluated levels of substitution. When at 30\% level, it significantly differed from the others, and was similar only to black sunflower replacingre $50 \%$ of Brachiaria, evidencing no significant difference. At $70 \%$ level, the canola byproduct resulted in the maximum production of $\mathrm{NH}_{3}-\mathrm{N}$, that is, as the percentage unit of that byproduct increased, it increased $0.86 \mathrm{~mL} / \mathrm{g}$ the production of $\mathrm{NH}_{3}-\mathrm{N}$.

The lowest production was observed for the inclusion of forage turnip and castor bean. The lowest production with the use of the castor byproduct at the $30 \%$ level $(\mathrm{P}<0.05 \%)$ was recorded. The forage turnip presented an increasing behavior in the evaluations with an increase of 0.48 $\mathrm{mL} / \mathrm{g} \mathrm{NH}$ - $\mathrm{N}$.

As reported by Freire et al. (2017), high contents of NDF were found when using canola and black sunflower (410.3 and 390.1), providing high levels of $\mathrm{CO}_{2}$ and $\mathrm{N}-\mathrm{NH}_{3}$

In the same way we observed a decline in methane production in vitro related to the content of unsaturated lipids present in byproducts of castor bean $(43.2 \mathrm{~g} / \mathrm{kg})$ and forage turnip (284.1 $\mathrm{g} / \mathrm{kg}$ ), lower levels of $\mathrm{CO}_{2}$ and $\mathrm{N}-\mathrm{NH}_{3}$ were registered when replacing Brachiaria grass.

Due to deleterious effects to ruminal microorganisms, unsaturated fatty acids are converted into saturated fatty acids by the mechanism known as biohydrogenation, which through the addition of hydrogen in the unsaturations, allows the reduction of their toxicity and utilization (Palmquist and Mattos, 2006). The use of saturated lipids in the diets after biohydrogenation promotes a reducing effect of ammonia and the elimination of $\mathrm{H}$ from $\mathrm{CHO}$ fermentation, increasing ruminal propionate 
production and reducing methanogenesis (Oliveira et al., 2009).

Substituting the Brachiaria grass with the co-products, for the production of VFA in the time interval of 48 hours (Table 3), we have the production of acetic, propionic and butyric acids.

Table 3. Production of Acetate, Propionate and Butyrate $(\mathrm{mL} / \mathrm{g})$ of biodiesel by products in different levels of substitution of Brachiaria grass.

\begin{tabular}{|c|c|c|c|c|c|c|c|}
\hline \multirow[t]{2}{*}{ Byproducts } & \multicolumn{4}{|c|}{ Replacement levels } & \multirow[b]{2}{*}{ Regression equation } & \multirow{2}{*}{$\mathrm{R}^{2}$} & \multirow{2}{*}{$\mathrm{P}$} \\
\hline & $0 \%$ & $30 \%$ & $50 \%$ & $70 \%$ & & & \\
\hline \multirow{5}{*}{$\begin{array}{l}\text { Forage turnip } \\
\text { Castor bean } \\
\text { Black } \\
\text { sunflower } \\
\text { Canola }\end{array}$} & & & & Acetate & & & \\
\hline & $35.37^{\mathrm{A}}$ & $38.19^{\mathrm{A}}$ & $12.54^{\mathrm{B}}$ & $24.10^{\mathrm{A}}$ & $\mathrm{Y}=36.981-0.251 \mathrm{x}$ & 0.404 & 0.0006 \\
\hline & $35.37^{\mathrm{A}}$ & $18.64^{\mathrm{C}}$ & $12.97^{\mathrm{B}}$ & $13.07^{\mathrm{B}}$ & $Y=35.420-0.751 x+0.006 x^{2}$ & 0.952 & $<.0001$ \\
\hline & $35.37^{\mathrm{A}}$ & $31.66^{\mathrm{B}}$ & $30.14^{\mathrm{A}}$ & $24.01^{\mathrm{A}}$ & $\hat{Y}=37.9397-0.0081 x-0.0017 x^{2}$ & 0.85 & 0.0002 \\
\hline & $35.37^{\mathrm{A}}$ & $31.04^{\mathrm{B}}$ & $30.21^{\mathrm{A}}$ & $30.21^{\mathrm{A}}$ & $Y=34.681-0.084 x$ & 0.639 & 0.0018 \\
\hline \multicolumn{8}{|c|}{ Propionate } \\
\hline \multirow{4}{*}{$\begin{array}{l}\text { Forage turnip } \\
\text { Castor bean } \\
\text { Black } \\
\text { sunflower } \\
\text { Canola }\end{array}$} & $16.61^{\mathrm{A}}$ & $17.01^{\mathrm{A}}$ & $5.37^{\mathrm{B}}$ & $11.18^{\mathrm{A}}$ & $Y=17.032-0.119 x$ & 0.416 & 0.0234 \\
\hline & $16.61^{\mathrm{A}}$ & $8.60^{\mathrm{C}}$ & $5.58^{\mathrm{B}}$ & $5.61^{\mathrm{C}}$ & $Y=16.657-0.361 x+0.002 x^{2}$ & 0.958 & $<.0001$ \\
\hline & $16.61^{\mathrm{A}}$ & $11.83^{\mathrm{B}}$ & $10.64^{\mathrm{A}}$ & $8.29^{\mathrm{B}}$ & $Y=16.182-0.115 x$ & 0.929 & 0.0036 \\
\hline & $16.61^{\mathrm{A}}$ & $10.64^{\mathrm{BC}}$ & $10.75^{\mathrm{A}}$ & $10.61^{\mathrm{AB}}$ & $Y=16.486-0.247 x+0.002 x^{2}$ & 0.923 & 0.1670 \\
\hline \multirow{5}{*}{$\begin{array}{l}\text { Forage turnip } \\
\text { Castor bean } \\
\text { Black } \\
\text { sunflower } \\
\text { Canola }\end{array}$} & & & & Butyrate & & & \\
\hline & $7.25^{\mathrm{A}}$ & $8.32^{\mathrm{A}}$ & $2.57^{\mathrm{B}}$ & $4.70^{\AA}$ & $Y=7.811-0.055 x$ & 0.412 & 0.0245 \\
\hline & $7.25^{\mathrm{A}}$ & $3.74^{\mathrm{C}}$ & $2.59^{\mathrm{B}}$ & $2.34^{\mathrm{C}}$ & $\mathrm{Y}=7.255-0.151 \mathrm{x}+0.001 \mathrm{x}^{2}$ & 0.956 & $<.0001$ \\
\hline & $7.25^{\mathrm{A}}$ & $5.34^{\mathrm{B}}$ & $5.20^{\mathrm{A}}$ & $3.50^{\mathrm{BC}}$ & $\mathrm{Y}=7.198-0.049 \mathrm{x}$ & 0,876 & $<.0001$ \\
\hline & $7.25^{\mathrm{A}}$ & $5.80^{\mathrm{B}}$ & $5.19^{\mathrm{A}}$ & $5.70^{\mathrm{AB}}$ & $Y=7.288-0.076 x+0.0007 x^{2}$ & 0.803 & 0.0007 \\
\hline
\end{tabular}

Evaluating the byproduct of castor bean for the production of acetic, propionic and butyric acids, it was observed inferior results to the other byproducts, justified by the presence of ricin, which decreases the digestibility and consequently the production of gases. Regarding the other by products studied, canola provided a high and stable production of acetic and propionic acids, even though it did not have the largest amount of fiber carbohydrates in its composition, but did not have antinutritional factors.

Forage turnip at $30 \%$ in the evaluations for VFA revealed a differential when compared to other foods, since at this level even having a high content of lipids in its composition, presents values higher than the others. Araújo et al. (2012) concluded that the level of forage inclusion increases the production of gases, demonstrating the effect of fiber on ruminal dynamics.

With respect to the production of butyric acid, it was influenced by the substitution of grass by the byproducts, with lower production in relation to the control group. This may be related to the high protein content of these byproducts that result in the formation of ammonium bicarbonate, from $\mathrm{CO}_{2}$ and ammonia, thus reducing the contribution of $\mathrm{CO}_{2}$ to the total gas production.

Some factors may directly influence ruminal fermentation and the amount of VFA produced, modifying the normal patterns. Kosloski (2009) reported that the type of carbohydrate in the diet, such as the cuticle surrounding the grains, the lignin of the cell wall of vegetables, the protein surrounding the starch granules, as well as excess lipids in the diet are barriers to bacterial hydrolytic activity.

The $\mathrm{pH}$ ruminal is a chemical and physiological factor that influences microbial growth and is influenced by the type of food consumed (Van Soest, 1994). The ruminal $\mathrm{pH}$ is a very important parameter for the ruminal fermentation study; thus, it was observed that the interaction of the replacement levels promote variation in ruminal $\mathrm{pH}$ in the interval of 48 hours.

In this evaluation of $\mathrm{pH}$, canola byproduct resulted in lower values, showing a quadratic effect in relation to the $\mathrm{pH}$ with increasing substitution, being $60.5 \%$ the level that promoted the maximum point. This behavior can be because the byproduct of canola increased the production of propionate, occurring sequestration of $\mathrm{H} 2+$ for the formation of this VFA. Orskov (1988) proposed that, in ruminal $\mathrm{pH}$ below 6.2, fiber digestion is reduced due to the sensitivity of fibrolytic bacteria and the optimal fiber digestion point occurs at $\mathrm{pH}$ values between 6.7 and 7.1. 


\section{Conclusion}

We concluded that, among the evaluated byproducts, the lowest production of methane was evidenced with the use of castor bean byproduct at 50 to $70 \%$ substitution levels. This resulted in a reduction of $0.37 \mathrm{~mL} / \mathrm{g} \quad \mathrm{CH} 4$, promoting satisfactory $\mathrm{pH}$ and $\mathrm{NH}_{3}$ levels for maximum rumen fermentation. It can be considered a quality alternative for the use of Brachiaria grass.

\section{Conflict of Interest}

The authors declare that there is no conflict of interest.

\section{Ethics Committee}

Care and handling of the animals used in the current study were conducted as outlined in the guidelines of the Universidade Federal de Campina Grande Institutional Animal Care and Use Committee (IACUC\# 089/2016).

\section{References}

Abdalla, A.L.; Silva Filho, J.C.; Godoi, A.R.; Carmo, C.A; Eduardo, J.L.P. Utilização de subprodutos da indústria de biodiesel na alimentação de ruminantes. Revista Brasileira de Zootecnia, 37: 260- 258, 2008. Araújo, D.R.C.; Carneiro, H.; Silva, A.M.A.; Silva, U.L.; Bernardi, T.M. Avaliação da degradabilidade in vitro, ácidos graxos voláteis e perdas energéticas através da produção total de gases, metano e dióxido de carbono de quatro espécies forrageiras em bovinos e ovinos. Revista Ciência e Produção Animal, 14: 203-206, 2012.

Archimède, H.; Eugène, M.; Marie, M.C.; Boval, M.; Martin, C.; Morgavi, D.P.; Lecomte, P.; Doreau, M. Comparison of methane production between $\mathrm{C} 3$ and $\mathrm{C} 4$ grasses and legumes. Animal Feed Science and Technology, 59-64, 166-1667: 2011.

Azevedo, R.A.; Bicalho, F.L.; Araújo, L.; Ribeiro Júnior, C.S.; Santos, A.C.R.; Jayme, D.G.; Geraseev, L.C. Technical and economic analysis of differents levels of macauba cake in diets for dairy cows. Archivos de Zootecnia, 62: 147-150, 2013.

Berchielli, T.T.; Pires, A.V.; Oliveira, S.G. Nutrição de ruminantes. Funep. $1^{\mathrm{a}}$ ed. Jaboticabal-SP. cap. 7, 2006. 192 p.

Bueno, I.C.S.; Vitti, D.M.S.S.; Louvadini, H.; Abdalla, A.L. A new approach for in vitro bioassay to measure tannin biological effects based on a gas production technique. Animal Feed Science and Technology, 41:153-170. 2008.

Fedorak, P.M.; Hrudey, S.E. A simple apparatus for measuring gas-production by methanogenic cultures in serum bottles. Environmental Technology Letters, 10(4): 425-432, 1983.

Freire, J.M.; Silva, A.M.A.; Carneiro, H.; Pereira Filho, J.M.; Rocha, L.B.; Bidler, D.C. In vitro degradation and gas production of brachiaria grass with levels of biodiesel byproducts. Acta Scientiarum Animal Sciences, 39: 175179, 2017.

Kozloski, G, V. Bioquímica dos ruminantes. $2^{\mathrm{a}}$ ed. Santa Maria: UFSM, 2009. 214 p.

Holtshausen, L.; Chaves, A.V.; Beauchemin, K.A.; Mcginn, S.M.; Mcallister, T.A.; Odongo, NE.; Cheeke, P.R.; Benchaar, C. Feeding saponincontaining Yucca shidigera and Quillaja saponaria to decrease enteric methane production in dairy cows. Journal of Dairy Science, 92: 2809-2821. 2009.

Oliveira, R.L.; Bagaldo, A.R.; Ladeira, M.M.; Barbosa, M.A.A.F.; Oliveira, R.L.; Jaeger, S.M.P.L. Fontes de lipídeos na dieta de búfalas lactantes: consumo, digestibilidade e N-uréico plasmático. Revista Brasileira de Zootecnia, 38: 553-559, 2009

Orskov, E.R. Nutrición proteica de los ruminantes. Zaragoza: Acribia, 1988. 178 p.

Palmquist, D.L.; Mattos, W.R.S. Metabolismo de lipídeos. In: Nutrição de ruminantes. $1^{\mathrm{a}} \mathrm{ed}$. Jaboticabal: Telma Teresinha Berchielli, Alexandre Vaz Pires e Simone Gisele de Oliveira. cap. 10, 2006. 292 p.

SAS -Statistica Analysis System. Cary: Institute Inc. User's Guide, 2003.

Silva, D.J.; Queiroz, A.C. Análise de alimentos: métodos químicos e biológicos. Viçosa: UFV, 2002.

Van Soest, P.J.; Robertson, J.B.; Lewis, B.A. Methods for dietary fiber, neutral detergent fiber, and non starch polysaccharides in relation to animal nutrition. Journal of Dairy Science, v.74: p.3583-3597.1991

Van Soest, P.J. Nutritional ecology of the ruminant. $2^{\text {nd }}$ ed. Ithaca: Cornell University Press, 1994.

Vitti, D.M.S.S.; Abdalla, A.L.; Silva Filho, J.C.; Del Mastro, N.L.; Maurício. R.; Owen, E.; Mould, F. Misleading relationships between in situ rumen dry mater disappearance, 
chemical analyzed and in vitro gas production and digestibility, of sugarcane baggage treated with varying levels of electron irradiation and ammonia. Animal Feed Science and Technology, 79:145-153.1999. 